\title{
Retraction: A Strain of an Emerging Indian Xanthomonas oryzae pv. oryzae Pathotype Defeats the Rice Bacterial Blight Resistance Gene xa13 Without Inducing a Clade III SWEET Gene and Is Nearly Identical to a Recent Thai Isolate
}

OPEN ACCESS

Approved by:

Martin G. Klotz,

Washington State University

United States

*Correspondence:

Frontiers Editorial Office

editorial.office@frontiersin.org

Specialty section:

This article was submitted to

Plant Pathogen Interactions,

a section of the journal

Frontiers in Microbiology

Received: 24 September 2020

Accepted: 24 September 2020

Published: 21 October 2020

Citation:

Frontiers Editorial Office (2020)

Retraction: A Strain of an Emerging Indian Xanthomonas oryzae pv. oryzae Pathotype Defeats the Rice Bacterial Blight Resistance Gene xa13 Without Inducing a Clade III SWEET Gene and

Is Nearly Identical to a Recent Thai

Isolate. Front. Microbiol. 11:609848.

doi: 10.3389/fmicb.2020.609848

\section{Frontiers Editorial Office*}

\section{A Retraction of the Original Research Article}

A Strain of an Emerging Indian Xanthomonas oryzae pv. oryzae Pathotype Defeats the Rice Bacterial Blight Resistance Gene xala3 Without Inducing a Clade III SWEET Gene and Is Nearly Identical to a Recent Thai Isolate

by Carpenter, S. C. D., Mishra, P., Ghoshal, C., Dash, P. K., Wang, L., Midha, S., et al. (2018). Front. Microbiol. 9:2703. doi: 10.3389/fmicb.2018.02703

The journal retracts the 13 November 2018 article cited above.

Experiments performed subsequent to publication, using genotype-verified, single seed-descent IR2R4, IRBB5B, and IRBB1B3 plants, revealed that IX-280 and SK2K2-3, though compatible with $\mathrm{xa} 5 \mathrm{a}$, are not compatible with xala 3 as originally reported. The discrepancy is postulated to be due to genotype contamination in the seeds used for initial characterization, as several older seed stocks labeled "IRBB1B3," including stocks used to pathotype these strains originally, when tested were found to be a mix of Xa1a3 and xala3 genotypes. The authors present the genome comparisons and TAL effector analysis for IX-280 and SK2-3 in a new manuscript, Carpenter et al., 2020 (new submission: https://www.frontiersin.org/articles/10.3389/fmicb.2020.579504/full).

The authors requested the retraction and sincerely regret any inconvenience this may have caused to the reviewers, editors and readers of Frontiers in Microbiology.

Copyright () 2020 Frontiers Editorial Office. This is an open-access article distributed under the terms of the Creative Commons Attribution License (CC BY). The use, distribution or reproduction in other forums is permitted, provided the original author(s) and the copyright owner(s) are credited and that the original publication in this journal is cited, in accordance with accepted academic practice. No use, distribution or reproduction is permitted which does not comply with these terms. 